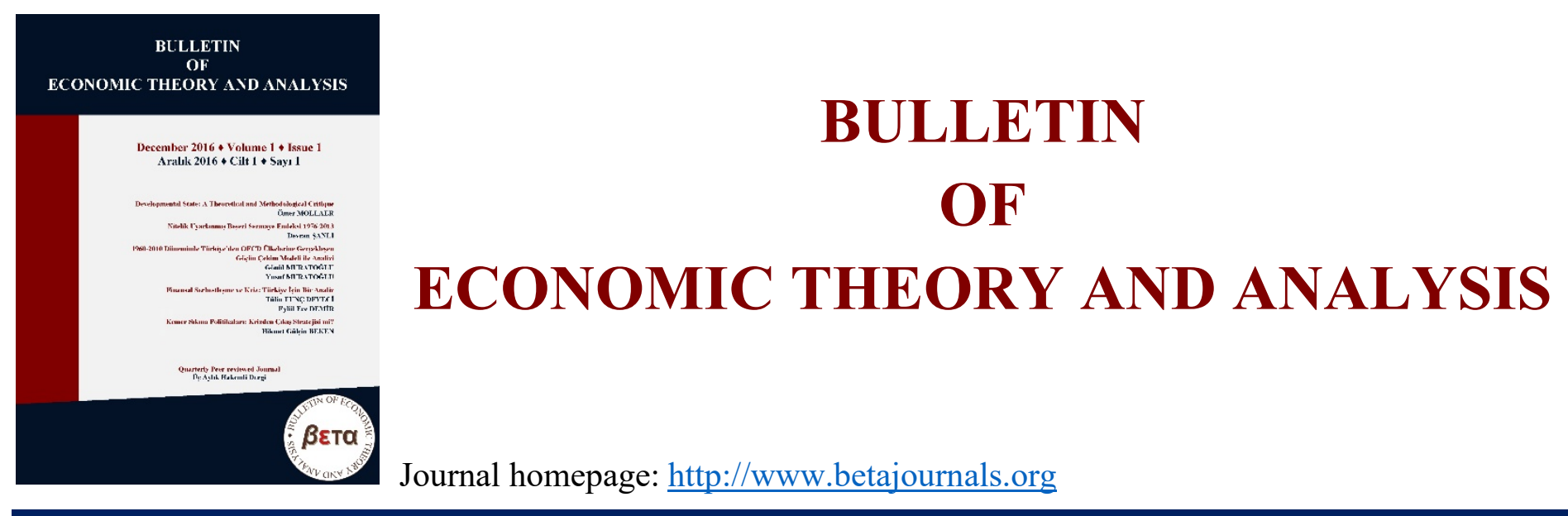

\title{
Piyasa Ekonomisi, Özgürlük ve Eşitlik: Friedrich August Von Hayek Üzerine Eleştirel Bir Değerlendirme
}

\section{Mehmet KANATLI $\odot$ https://orcid.org/0000-0003-2215-4038}

To cite this article: Kanatl1, M. (2021). Piyasa Ekonomisi, Özgürlük ve Eşitlik: Friedrich August Von Hayek Üzerine Eleştirel Bir Değerlendirme. Bulletin of Economic Theory and Analysis, 6(2), 131-153.

Received: 09 Dec 2021

Accepted: 28 Dec 2021

Published online: 31 Dec 2021

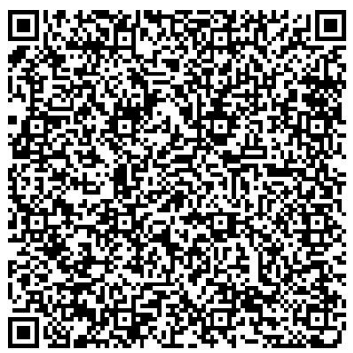




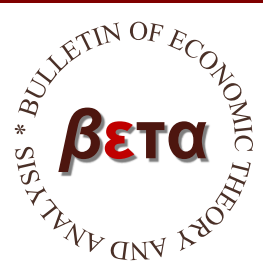

\title{
Bulletin of Economic Theory and Analysis
}

\author{
Volume VI, Issue 2, pp. 131-153, 2021 \\ http://www.betajournals.org
}

Original Article / Araştırma Makalesi

Received / Alınma: 09.12.2021 Accepted / Kabul: 28.12.2021

\section{Piyasa Ekonomisi, Özgürlük ve Eşitlik: Friedrich August Von Hayek Üzerine Eleştirel Bir Değerlendirme \\ Mehmet KANATLI ${ }^{\mathrm{a}}$ \\ a Öğr. Gör. Dr, Hitit Üniversitesi, İktisadi ve İdari Bilimler Fakültesi, Siyaset Bilimi ve Kamu Yönetimi Bölümü, Çorum, TÜRKIYE (- https://orcid.org/0000-0003-2215-4038}

\section{ÖZ}

Bireysel özgürlük, eşitlik ve adalet gibi olguların piyasa ekonomisine içkin kılınması birçok liberal teorisyen tarafından liberalizmin alâmetifarikası olarak değerlendirilir. Piyasa ekonomisinin katıksız savunucusu olan Friedrich August Von Hayek için de bu durum farksızdır. Bireyi ontolojik bir kategori olarak sosyal teorisinin merkezine alan Hayek'in nazarında özgürlük, bireysel özgürlük, eşitlik ise hukuk önünde eşitlik anlamlarına gelmektedir. Adalet ise, bireyin özgürce davranışlarını sergilemesine zemin hazırlayan piyasa ekonomisin kanun hâkimiyetinde işleyip işlemediğinin ölçütünden ibarettir. Bu doğrultuda, bu çalışmanın amacı; Hayek'in piyasa ekonomisi, özgürlük ve eşitlik arasında kurmuş olduğu zorunlu ilişkinin temel çerçevesini çizmek ve bu bağlamda 'Hayekçi Özgürlük Anlayışı, biçimsel eşitlikler maskesi altında gizlenen bir masaldan mı ibarettir? sorusuna cevap aramaktır. Çalışmada ileri sürülen temel hipotez; özel mülkiyet kavramının çarpıtılarak özgürlüğe içkin kılınması, doğal eşitsizlikler ile yapay eşitsizliklerin biçimsel eşitlik/hukuk önünde eşitlik şeklinde tekdüzeleştirilmesi ve her şeyden önemlisi de piyasa özgürlüğünün siyasal özgürlüğe öncelenmesi Hayekçi Özgürlük Anlayışı’nın belli başlı açmazlarını oluşturmaktadır.

Anahtar Kelimeler Piyasa Ekonomisi, Planlı Ekonomi, Özgürlük, Eşitlik, Hayek

\section{JEL Kodu}

D63, P10, P51

ILETIŞIM Mehmet KANATLI $\bowtie$ mehmet.kanatli@hotmail.com $\risingdotseq$ Hitit Üniversitesi, İktisadi ve İdari Bilimler Fakültesi, Siyaset Bilimi ve Kamu Yönetimi Bölümü, Çorum, Türkiye 


\title{
Market Economy, Freedom and Equality: A Critical Assessment of Friedrich August Von Hayek
}

\begin{abstract}
One of the trademarks of liberalism is to make a linear and strict relation between market economy and notions such as individual freedom, equality and justice. This claim is same for Frierdrich August Von Hayek, one of the pure defenders of market economy. By formulating individual as an ontological category in his premises of social theory, Hayek claims that freedom is nothing but individual freedom, while equality means equality before the law. Justice, on the other hand, consists of criterion of whether the market economy, which paves the way the individuals to act freely, operates under the rule of law. In this sense, the main objective of this study is to draw basic framework of the relation between freedom, equality and market economy that Hayek makes and to seek an answer to the question of 'Is Hayek's understanding of freedom nothing but an utopia formulated under the mask of formal equalities?'. The main hypothesis put forward in the study is that; by distorting the concept of private property for the sake of making it immanent to freedom and homogenising artificial inequalities stemmed from market economy under the mask of equality before the law, Hayek's theory of freedom provides an illusionary-based freedom. More significantly, being prioritized market freedom over political freedom in Hayek's theory of freedom

indicates how Hayekian understanding of freedom leads to unfreedom for masses.
\end{abstract}

Keywords

Market Economy, Planned Economy, Freedom, Equality, Hayek

JEL Classification D63, P10, P51

\section{Giriş}

'Serbest Piyasa Ekonomisi, özgürlük ve eşitliğin hem toplumsal hem de bireysel zeminde yaşanmasını sağlayan biricik unsurdur savı', klasik liberalizmin pek çok savunucusu tarafından 19.yüzyılın sonunda dile getirilmeye başlanmıştır. Özellikle İkinci Dünya Savaşı sonrasında Batı dünyasında yükselmeye başlayan ve 1950-1970 yılları arasında Altın Çağ'ını yaşayan refah devleti uygulamasının planlı iktisadın bir varyasyonu olduğu ve bireysel özgürlük ve eşitliğe ket vurduğunu iddia eden neo-liberalizm savunucuları tarafindan 1980'li yıllardan itibaren bu sav tekrardan 1sıtılarak teorik bir araca dönüştürülmüştür (Neuhouser, 2013: 196). Bu dönemde, özellikle devletin başat aktör olduğu planlı iktisadi modellerin uygulandığı toplumlarda özgürsüzlük ve eşitsizliğin temel nedeni olarak devletin ekonomiye müdahalesinin gösterildiği neo-liberal argümanların merkezinde gerçek özgürlüklerin ve eşitliklerin yaşanması için serbest piyasa ekonomisine dönmenin elzem olduğu görüşü liberal düşünürler arasında gittikçe önem arz etmeye başlamıştı. Bu gelişmeler neticesinde, refah devleti uygulamalarına cephe savaşı açan liberal teorisyenler klasik liberalizmi neo-liberalizm şeklinde revize etmiştir. Bu revize ediş sürecinde piyasa ekonomisi savunucularının en çok savundukları argümanların başında ise, 
Friedrich August Von Hayek'in piyasa ekonomisi, özgürlük ve eşitlik arasında kurmuş olduğu teorik aç11ım gelmektedir. (Cooper, 2011: 372; Rodrigues: 2013: 1006). Hayek'in sosyalist ekonomi başta olmak üzere refah devleti uygulamaları da dâhil herhangi bir planlı iktisat üzerine inşa edilen toplumsal formasyonlarda özgürsüzlük ve eşitsizlik durumlarının yaşanacağını iddia ettiği ve 1942 yılında yayımladığı Kölelik Yolu ile 1950 yılında yayımlanan Özgürlüğün Anayasası ve son olarak da 1973 yılında kaleme aldığı Yasa Yasama ve Özgürlük adlı eserler, günümüzde birçok neo-liberal teorisyenin bu doğrultuda başvurduğu temel yapıtlar arasında yer almaktadır (Kanatlı, 2020: 683). Hayek, adı geçen bu temel eserlerinde özgürlük, piyasa ekonomisi ve eşitlik arasındaki ilişkiye dair teorik açılımlar yapmıştır. Bireyi ontolojik bir kategori olarak değerlendiği sosyal teorisinde Hayek, teorik çıktılarını elde ederken kavramsal dikhotomiler üzerinden özgürlügün, eşitliğin ve piyasa ekonomisinin ne anlama geldiğini açıklar. Bu yöntemin Hayek’e kazandırdığı kavramsal çözümlemede en önemli ikilik ferdiyetçilik ve kolektivizm dikhotomisidir. Çünkü bireyi sosyal teorisinin ontolojik kategorisine yerleştiren Hayek’te piyasa ekonomisi, özgürlük, eşitlik ve adalet gibi nosyonlar bireycilikten/ferdiyetçilikten neşet ederken, özgürsüzlük, kölelik, eşitsizlik ve planlı iktisat ise ferdiyetçiliğin tabiri yerindeyse düşmanı olan kollektivizimden türetilir. Bruce Caldwell bu durumun, "Hayek'in sosyal teorisinin neredeyse tamamını sosyalizm ve planlı iktisadı eleştirmeye adamasından" (Caldwell, 1988: 519) kaynaklandığını ifade eder. Pek tabi ki de Caldwell'in yaptığı bu tespit önemli olmakla beraber, konumuz açısından bu tespiti daha da önemli kılan unsur; Hayek'in eşitlik, adalet ve özgürlük gibi olguları piyasa ekonomisi-planlı iktisat dikhotomileri üzerinden formülleştirmiş olmasıdır.

Hayek, "piyasa ekonomisinin gerçek özgürlükler ve eşitliklerin yaşanmasını sağlayan yegâne olgu" (Hayek, 2011) olduğunu ifade eder. Piyasa ekonomisinin Hayek’te bu derece önemli olmasının nedeni, Kenneth Boulding’in de belirttiği üzere, 'Hayek'in sosyal teorisinde bireyin ontolojik bir kategori olarak ele alınmasının yanı sıra, birey-devlet-toplum formasyonunun atomistik olmayan birey üzerinden inşa edilmeye çalışılmış olmasıdır” (Boulding, 1981: 33). Dolayısıyla, bireyin Hayek tarafından nasıl ele alındığı, özgürlük ve eşitlikten ne anlaşılması gerektiği ve her şeyden önemlisi de neden ancak ve ancak özel mülkiyet kurumu üzerine inşa edilen kapitalist piyasa ekonomilerinde gerçek bireysel özgürlükler ve eşitlikler yaşanabilir yönündeki Hayekçi sav, aynı zamanda, bu çalışmanın temel çerçevesini de oluşturmaktadır.

Hayek Batı uygarlığının tarihte edindiği en büyük kazanımın özgürlük ideali olduğunu fakat bu “özgürlük idealinin 20.yüzyıldan itibaren kolektivizm kılıfı altında totaliter yönetimlerin ortaya 
çıkmasıyla tehlikeye atıldığını" (Hayek, 2011; 23-24) iddia eder. Gerçek özgürlüğü bireysel özgürlük olarak, gerçek eşitliği ise yasa önünde eşitlik olarak kodlayan Hayek'in sosyal teorisinde piyasa ekonomisi üzerine inşa edilen ve hukukun egemenliğinde olan toplumsal formasyonlarda yaşayan bireyler hem adil bir toplumda yaşamaktadırlar, hem de gerçek özgürlük ve eşitliği yaşamaktadırlar. Aksi durumda olan yani sosyalist iktisadi bir modelin veya planlı iktisadi bir modelin uygulandığı totaliter rejimlerde açığa çıkan toplumsal formasyonlarda ise bireysel özgürlüklerin yerini bireysel kölelik almaktadır. Benzer şekilde piyasa ekonomisinin uygulanmadığı totaliter sistemlerde gerçek eşitlik anlamına gelen hukuk önünde eşitliğin yerini de maddi eşitlik üzerinden temellendirilen eşitsizlik almaktadır ki bunun adı adaletsizlikten başka bir şey değildir (a.g.e: 46). Görüldüğü üzere, Hayek, piyasa ekonomisi, özgürlük ve eşitlik arasında kurmuş olduğu ilişkide özgürlüğü bireysel özgürlükler, eşitliği ise hukuk önünde eşitlik olarak kodlandırmaktadır. Daha da önemlisi ise, Hayek'in bireysel özgürlüklerin ve eşitliklerin yaşanıp yaşanmadığı üzerinden bir toplumda adalet anlayışının olup olmadığını analiz etmesi ve bu durumu toplumda uygulamada olan ekonomik modele indirgemesidir. Bu bağlamda, bu çalışmanın temel amacı; Hayek'in piyasa ekonomisi, özgürlük ve eşitlik arasında kurmuş olduğu ilişkinin temel çerçevesini çizmek ve bu ilişkinin teorik açmazlarına değinmektir. Bu doğrultuda çalışma üç temel bölümden oluşmaktadır. Birinci bölümde Hayek'in özgürlükten ne anladığı analiz edilirken, ikinci bölümde ise, Hayekçi özgürlük ve eşitlik anlayışlarının yaşanmasını koşullandıran piyasa ekonomisinin Hayek'in özgürlük teorisindeki elzemliliği açıklanmaktadır. Son bölümde ise, 'Hayek'in biçimsel eşitlikler kılıfı altında formüle ettiği özgürlük anlayışı esasında bir masaldan mı ibarettir?' sorusuna cevap aranmaktadır.

\section{2. Özgürlüğün Haritalandırılması: Ontolojik Bir Kategori Olarak Birey ve Bireysel Özgürlük:}

Hayek'in liberalizm içerisinde konumlandırılan sosyal teorisinde birey ontolojik bir kategori olarak ele alınmaktadır. Dolayısıyla, birey-toplum-devlet formasyonunu oluşturan sosyal teoride özgürlük, eşitlik ve adalet gibi nosyonlar bireyin merkeze alındığı teorik zeminden türetilir. Bu bağlamda birey kavramı Hayek açısından özgürlük ve eşitlik gibi nosyonları türetecek olan yegâne unsur olduğu için, Hayek'in birey kavramından ne anladığını açıklamak, daha da doğrusu bireyin metodolojik bireycilik yöntemi ${ }^{l}$ ne haiz bir biçimde araştırma nesnesi olarak Hayek

\footnotetext{
${ }^{1}$ Metodolojik Bireycilik Yöntemi genel anlamda toplumsal olguların bireyler arası ilişkilerden kaynaklandığı açıklayan bir yöntemdir. Bu yöntem toplumun tek tek bireylerin toplamından ibaret olduğunu varsaydığı için bireylerin
} 
tarafından nasıl kodlandığını analiz etmek, aynı zamanda Hayek'in özgürlükten ne anladığının da cevabinı verecektir.

Hayek için birey çoğu liberal düşünürün formüle ettiği atomistik bireyden farklı olarak, sosyal yönü olan, çevresi ile iletişimde olan ve bu iletişim sayesinde kendisini var eden bir özneye tekabül etmektedir (Hayek, aktaran Kanatlı: 2021: 152). Hayek’in özneleştirdiği bireyin temel olarak iki özelliğe sahip olduğu belirtilmelidir: rasyonel eylemde bulunan ve ahlaki davranabilme potansiyeline sahip olan özneler olarak birey. Tarihsel olarak Modern Batı Uygarlığı'na ilham veren ve bu uygarlığı ortaya çıkarmış olan özgürlük idealini gerçekleştiren ve gerçekleştirecek olan insan, rasyonel ve ahlaki davranabilme özelliklerini sergileyen insandır (Hayek, 2011: 24). Çünkü Hayek için birbirinin tamamlayıcısı konumunda olan özgürlük nosyonunu gerçekleştirme ile ahlaki davranabilme potansiyelini açığa çıkarabilme durumları, özne kategorisine yerleştirilen ve tarihsel süreçte açığa çıkan bireye içkindir. Bir başka deyişle, Hayek'in nazarında, rasyonel fakat özgür olmayan bireyin ahlak ile ilişkisinden söz edilemez (Yiğit, 2014: 41). Bireyin rasyonel olması demek bireyin aklını sadece kişisel çıkarları için kullandığı yani amaca ulaşma yolunda aklı sadece araçsal biçimde kullandığı anlamına gelmemektedir. (Hayek 2011: 43) Aksine Hayek için akıl, sosyal bir canlı olan insana ahlaki sorumluluklar da yükleyen; bir başka ifade ile, bireylerin davranışlarında ahlaki olmayı da koşullandıran bir olgudur. Dolayısıyla Hayek’te ahlak kavramı, Gülsevin Yiğit'in ifadesiyle;

“(.....) aslında bireysel bir temele ve bireyin, ancak özgür bırakıldığında, kendi çıkarı kadar, gerektiğinde içinde yaşadığı toplumun çıkarı için de kişisel fedakârlıklara hazır olması gerektiğine dayanır. Kişisel sorumluluk dünyasının dışında iyiliği ve kötülüğü ayırt etmek zordur. İnsanlara, ancak, kendi şahsi çıkarlarına ilişkin sorumluluklar yükleme ve gerektiğinde onları feda etme özgürlüğü tanındığı zaman, kararlarının ahlaki değerlerinden söz edilebilir. Hayek'in düşüncesinde ahlak kavramı, temelde bireysel özgürlük ve sorumluluk sorunundan koparılamaz. Özgür olmayan bir bireyin ahlak ile ilişkisinden söz edemeyiz”(Yiğit, 2014: 42 ).

Özgürlüğün Anayasası adlı eserinde özgürlük idealinden ne anlaşılması gerektiği bağlamında ele aldığı bireysel özgürlüğü siyasal teori, ahlak, antropoloji ve hukuk alanında inşa etmeye çalışan Hayek'in özgürlük analizi, kavramsal bir iğdişleştirmeye dayanır. Bu bağlamda

toplamından fazla olarak değerlendirilecek her türden sosyal olgu ve veriyi reddeder. Bu konuda detaylı bilgi için bkz: Jack, Turner (2011). "Individualism", The Encyclopedia of Political Science, Edited by George Thomas Kurian, Washington: CQ press, pp: 779-780; Mehmet, Okyayuz (1999). "Yöntembilimsel Bireycilik ve Marksist Toplum Kuramı: Yetmişli Yıllarda Federal Almanya'da Bir Bireycilik/Toplumculuk Tartı̧̧ması, Marksizm ve Gelecek, 16, (1), pp: 71-89. 
Hayek, özgürlüğün ne anlama geldiğini açıklarken özgürlük olgusunun analizini, özgürlük kavramının üzerindeki özgürlüğe dair çarpıtmalardan arındırarak yapmaya çalışır. Bir başka deyişle, Hayek' in özgürlük teorisinde özgürlük kavramı tarihsel bağlamda 'zorunlu olarak üzerinde

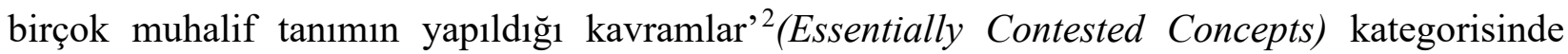
değerlendirilir. Bu Özgürlük nosyonu, "Özgürlük" (liberty) kavramı ile "hürriyet" (freedom) kavramlarının muğlâklaştırılması ve çarpıtılması sonucunda en çok zarar gören sosyal bir değerdir (Hayek, 2011: 32). Bu muğlâklığı ve çarpıtmayı "özgürlük (liberty) kavramı özel bir içerik verilinceye kadar hiçbir anlama gelmeyecek ve kelime küçük bir mesajla istenilen bir içeriğe bürünüp çarpitılacaktır” (a.g.e) tespiti üzerinden aşmaya çalışan Hayek, özgürlüğü hürriyet anlamına gelen İngilizce freedom kavramı üzerinden temellendirir. Bu tespiti yaptıktan sonra Hayek, geliştirmiş olduğu özgürlük teorisinde gerçek özgürlük olan bireysel özgürlüğü ferdiyetçilik-kollektivizm dikhotomisi üzerinden ele almaktadır. Bu şekilde bireysel özgürlüğün mahiyetini, önemini ve nasıl muhafaza edilmesi gerektiğini açıklayan Hayek, bireysel özgürlüğü kodlarken özgürlüğün kabaca beş farklı veçhesinden bahseder: i-) 'İcbarın Yokluğu Anlamında Özgürlük’; ii-) ‘Siyasi Özgürlük’ iii-) ‘İç Özgürlük’ veya ‘Metafizik Özgürlük’ iv-) ‘'̇ktidar/Güç Anlamında Özgürlük' ve son olarak da v-) 'Yasalarla Güvence Altına Alınmış İdeal Bireysel Özgürlük'-ki ben bu son özgürlük türüne çalışmanın devamında "Hayekçi Özgürlük” diyeceğim.

“İcbarın Yokluğu Anlamında Özgürlük”ten kast edilen şey bir başkasının ya da başkalarının keyfi iradesinden kaynaklı icbarına maruz kalmama durumu olarak özgürlüktür. Bu türden bir özgürlük tanımı pek tabi ki ferdi ya da şahsi hürriyet anlamına gelecektir (a.g.e: 38). Fakat hukuk devletinde olan yasalarca belirlenen ve devletin meşru zemin çerçevesinde kullanma tekeline sahip olduğu icbarın bütünüyle yokluğu anlamında bir özgürlük Hayek açısından özgürsüzlük durumuna yol açacaktır. Çünkü özgürlüğün yaşanabilmesinin ön koșulu, bireylerin toplamından ibaret olan toplumda her bireyin kendisini özgürce gerçekleștirebilmesini sağlayacak kuralları uygulayan bir otoritenin-ki bu devletten başkası olmayacaktır- icbarını gerektirecektir. Aksi takdirde keyfiliğe dayalı icbarlara maruz kalmak bireysel özgürlükleri ortadan kaldıracak bir gelişme olacaktır. (a.g.e: 40).

\footnotetext{
${ }^{2}$ Gallie tarafindan geliştirilen bu kavrama göre özgürlük, adalet, eşitlik ve benzeri birçok kavram tarihsel süreçte kavramı kullananlardan bağımsız olarak anlam kaybı yaşayarak çoğu kere birbirinin zıttı anlamlarına bile gelmiştir. Bu konuda detaylı bilgi için bkz.: W. B. Gallie (1955). "Essentially contested concepts", Proceedings of the Aristotelian Society, Vol: 56, Issue: 2, pp: 167-169.
} 
Özgürlüğün ikinci veçhesi olan 'Siyasi Özgürlük' “insanların hükümetlerini seçmeye, yasama sürecine ve idarenin denetimine katılım” (a.g.e: 41) anlamına gelen özgürlüktür. Hayek siyasi özgürlüğün zorunlu olarak bireysel özgürlüğü koşullandırmadığını veya bireysel özgürlük ile siyasi özgürlüğün çelişebileceğini iddia eder. Bu iddiasını dile getirirken Hayek, tekrardan ferdiyetçilik ve kolektivizm dikhotomosine başvurur: "Siyasi özgürlük, kavramımızın bir bütün olarak insan grupları için kullanılmasından-ki bu onlara bir tür kolektif özgürlük vermektedirtüretilir... Fakat bu anlamda özgür toplum illaki özgür insanların toplumu olmadığı gibi, birey olarak özgür olmak için bu kolektif özgürlükten pay sahibi olmanız da gerekli değildir” (a.g.e). Dolayısıyla Hayek'e göre, siyasal özgürlüğü kısıtlı olan biri-mesela mülteci olduğu bir ülkede oy verme hakkına sahip olmayan bir birey- pek tabi ki de bireysel özgürlüğünü yaşayabilecektir. Bir başka örnek verilecek olursa, siyasal özgürlüğe sahip bir birey kölelikten yana oy verebileceği veya kendini bir köle olarak akitle bağlayabileceği için (a.g.e: 42) sonuçta bu tür bir özgürlük bireysel özgürlügü sönümlendirecek bir özgürlük olacaktır. Kısacası, Hayek’in özgürlük teorisinde siyasi özgürlük, bireysel özgürlüğün karşısında yer alan kolektif özgürlüğe tekabül etmektedir ki bu durumda, Senem Kurtun da belirttiği üzere, "siyasal yönetim sürecinde söz sahibi olan bir halkın özgür olacağının garantisi verilemez, ayrıca bir bireyin özgür olabilmesi, onun bu kolektif özgürlük kavrayışında bulunduğu yerle de ilişkili olamaz (Kurt, 2006: 202).

Özgürlüğün bir diğer veçhesi olan 'İç Özgürlük veya 'Metafizik Özgürlük' gerçek özgürlügün gerçekleşeceği sosyal alana tekabül etmediği için Hayek tarafindan olumsuz bir özgürlük durumu olarak kodlanır. Hayek bu bağlamda 'İç Özgürlüğü' (inner freedom); 'kişinin, faaliyetlerinde o zamana bağlı saik veya şartın değil de, kendi bilinçli iradesi, aklı ya da öteden beri taşıdığı kanaatinin k1lavuzluğunu takip etmesine işaret eden” (Hayek, 2011: 43) durum şeklinde tanımlar. İç Özgürlük bireysel özgürlüğün gerçekleşmesine en yakın özgürlük gibi görünse de, Hayek’e göre İç Özgürlük bireysel özgürlüğü sonlandıran daha doğrusu onu çarpıtan bir özgürlük anlayışına dayanmaktadır. Çünkü "iç özgürlüğün mefhumu muhalifi başkalarından gelen icbar değil, geçici hislerin, moral ve zihni zafiyetin baskısıdır” (a.g.e:). Bu doğrultuda, Hayek açısından daha da önemli olan şey, İç Özgürlük bireyin bilgisizlik ve hurafe peşinde koşmasına ve ihtiraslarının esiri olmasına yol açan bir içeriğe sahip olma potansiyeline haiz olmasıdır. Dolayısıyla Hayek'in özgürlük teorisinde İç Özgürlük veya Metafizik Özgürlük, hem sosyal yalıtıma hem de, Atilla Yayla’nın da belirttiği üzere, "bireyin özgür olma durumu diğer insanlar tarafından yapılan bir zorlamadan değil, tamamen geçici duygulardan ahlaki ve zihni 
zayıflılıklardan kaynaklanan" (Yayla, 2000: 26) bir duruma tekabül ettiği için gerçek özgürlüğe ters bir durum oluşturur. Daha da önemlisi, tıpkı Siyasi Özgürlük’teki özgürsüzlük durumunun bir benzeri de İç Özgürlük’te yaşanmaktadır. İç özgürlük ile siyasi özgürlügün özgürsüzlük durumu bağlamında örtüştükleri noktayı Hayek şu şekilde özetler:

“Açıktır ki, sadece oy hakkına sahip olmakla köle özgür hale gelmez ve hiçbir "iç özgürlük” boyutu da-her ne kadar idealist filozoflar bizi aksi yönde iknaya çalışsalar da-onu kölenin dışında bir şey yapmaz” (Hayek, 2011: $50)$.

Ferdiyetçilik-kollektivizm dikhotomisi düzleminde özgürlüğe dair analiz yapan Hayek'in eleştirel bağlamda ele aldığı bir diğer özgürlük çeşidi olan İktidar/Güç Anlamında Özgürlük bir tür illüzyona işaret etmektedir. Bu bağlamda, özgürlük kelimesinin istediğimi yapabilirim şeklinde bir yanılgıya yol açacağını dile getiren Hayek' in nazarında “özgürlüğün güç ve kudretle tanımlanması bir kez kabul edilmeye görsün, artık "özgürlük” kelimesinin cazibesinin bireysel özgürlüğü tahrip eden düzenlemelere mesnet bulmak için” (a.g.e: 44) çarpıtılacaktır. Güç ve iktidar kavramlarının kolektif söylemler doğrultusunda formüle edildiği taktirde, İktidar/Güç Anlamında Özgürlük” anlayışının bireysel özgürlüğe en büyük tehlikeyi oluşturacağını iddia eden Hayek, bu tür özgürlük illüzyonunun totaliter devletlerde toplumsal özgürlük adına bireysel özgürlüklerin feda edilmesiyle sonuçlandığını belirtir. Çünkü güç anlamındaki özgürlüğün maddi eşitlik bağlamında değerlendirilmesi tabiatıyla özgürlüğün servet ile tanımlanmasına yol açar ve bu da, özgürlük kelimesinin servetin yeniden dağıttılmasına yönelik totaliter bir yeniden dağıtımcı cazibenin istismarını mümkün kılar (a.g.e: 46). Oysa gerçek bireysel özgürlük, doğrudan paraya veya maddiyata dayalı güç ve iktidar sahibi olmayı zorunlu olarak koşullandıran bir özgürlük değildir. Fakir olan birinin de bireysel özgürlüğe sahip olabileceğini dile getiren Hayek bu durumu şöyle özetler: "Lüks ve rahat içinde ama prensinin emrine amade yaşayan saray adamı, fakir bir çiftçi veya sanatçıdan çok daha özgür; kendi hayatını yaşama ve yararlılık bakımından kendi tercihlerini seçmede çok daha az muktedir olabilir" (a.g.e.).

Gerçek özgürlüğün üzerindeki muhtelif çarpıtmaları ortadan kaldırmak için özgürlüğündaha doğrusu özgürsüzlüğün-farklı veçhelerini iğdiş ederek haritalandıran Hayek, özgürlük teorisinde ideal/gerçek özgürlüğün ne anlama geldiğini ve nasıl korunması gerektiğini formüle etmiştir. Her şeyden evvel, Hayek'in nazarında özgürlük bir tabiat durumu olmayıp, bir uygarlık mamulüdür. Dolayısıyla, tarihsel olarak özgürlük idealini açığa çıkaran tarihteki bireysel 
mücadelelerdir. Tarihi birikim ve tecrübe ile açığa çıkan özgürlük mücadelesi ve özgürlüğün kendisi, soyut akıldan türetilen tasarımlar neticesinde değil, bilakis, değeri tecrübe edildikten sonra toplumsal ve siyasal müesseselerle açığa çıkmıştır (a.g.e: 99). Bireyin varoluşsal amaçlarından birihatta en önemlisi- olan özgürlük, tarihsel olarak özel bir değer olmanın yanı sıra, birey-toplumdevlet formasyonunun yaratılmasında "çoğu moral değerlerin şartı ve menşeidir" (a.g.e: 30 ). Bireytoplum-devlet formasyonunda eşitlik, ahlak ve özgürlük ilişkisinin kurucu öznesi olan özgürlük, Hayek tarafından en basit haliyle "bir insanın başkalarının keyfi zorlaması altında kalmaksızın davranabilmesidir" (a.g.e: 38) şeklinde tanımlanmaktadır. Bu bağlamda, Hayekçi özgürlük anlayış1-her ne kadar Hayek Negatif Özgürlük ve Pozitif Özgürlük ayrımlarının biçimsel ayrımlar olduğunu oysa özgürlüğün tek olduğunu ifade etse de- ${ }^{3}$ modern siyasal teoride Isaah Berlin'in formüle ettiği Negatif Özgürlük anlayışına tekabül etmektedir. Özgürlüğün negatif içerikli olması, tabiatıyla "bireyin teminat altına alınmış bir alana sahip olmasını, çevresinde başkalarının müdahale edemeyeceği bir hal ve şartlar kümesinin mevcudiyetini gerektirir” (a.g.e: 40). Bireysel özgürlüğün sosyal alanda cereyan eden bir etkinlik olması hasebiyle devlet ve toplum arasındaki ilişki de birey üzerinden tanımlanmak zorundadır. Bu bağlamda, Hayek de klasik liberalizmin savunduğu 'ne kadar çok devlet müdahalesi o kadar az özgürlük' düsturundan hareket etmektedir. $\mathrm{Bu}$ düstur bizlere, devletin özgürlüğü garanti altına alacak olan yasalardan kaynaklı icbar tekelini kendi özgürlüklerimizin savunulması için meşrulaştırılacağını gösterir. Hayek bu durumu şu şekilde açıklar:

“İdeal bir özgür toplum icbar tekelini devlete tevdi ederek ve devletin bu gücünü fertlerden gelen icbarı önlemenin gerektiği durumlarda sınırlamaya çalışarak mukabelede bulunmuştur. Bu ancak devletin, diğerlerinin müdahalesi karşısında bireylere ait tanınan özel alanları korumasıyla ve bu özel alanları, spesifik tayin ve tahsisle değil de, bireyin, yönetimin farklı durumlarda ne yapacağını kendisine beyan eden kurallara güvenerek kendi alanını belirleyebileceği şartlar yaratmak sureti ve sınırlandırmasıyla mümkündür” (Hayek, 2011: 51-52)

Devleti toplumun oluşturduğu zımni bir mukavele neticesinde açığa çıkan tarihsel bir olgu olarak ele alan Hayek, bireysel özgürlüklerin yaşanması bağlamında yukarıdaki alıntıdan da anlaşılacağı üzere iki önemli enstrümana başvurur: i-) 'Hukuk Egemenliği veya Kanun Hakimiyeti' ve ii-) 'Özel Mülkiyet'. Hayek' in indinde hukuk egemenliği “devletin bilinen bir kuralı tatbik etme dışında bireyi asla icbara konu etmemesi gerektiği manasına gelmesi münasebetiyle, yasama

\footnotetext{
${ }^{3}$ Hayek bu durumu şu şekilde açıklar: "Vakıa diğer anlamların bazılarında farklı özgürlük türlerinden, “...den özgürlükler (freedoms from)" ve “....e özgürlük (freedoms to)” ten söz etmek caiz olabilir, ama bizim anlayışımızda özgürlük tek olup, farklılık nevi açısından değil düzey açısındandır” (Hayek, 2011: 39).
} 
yetkileri dâhil tüm devlet yetkileri üzerinde bir tahdit tesis eder” (a.g.e: 311 ). Burada altı çizilmesi gereken husus; özgürlüğün gerçek anlamda uygulanabilmesi ve özgürsüzlük durumlarının ortadan kaldırılması için icbarın devlet tarafından kullanılmasının meşru olacağıdır. Çünkü hukuk egemenliği, bireysel özgürlüğü temele alan yasaların menşei olacağı için, 'hukuk egemenliği ilkesi' de "yasaların ne olması gerektiğine ilişkin, özel yasaların sahip olması gereken vasıflara ilişkin bir doktrindir" (a.g.e.). Dolayısıyla, Hayek'in özgürlük teorisinde hukuk egemenliği ilkesi, anayasacılıktan da öte bir içeriğe sahip olup, tüm yasaların belli ilkelere göre düzenlenmesini zorunlu k1lan bir ilkedir (Cooper, 2011: 379). Görüldüğü üzere kanun hâkimiyeti veya hukuk egemenliği ilkesi Hayek'in özgürlük teorisinde bireysel özgürlüğün mahiyetini ve teminatını oluşturan en önemli unsurların başında gelmektedir. Hayek hukuk devletinin vazgeçilmez unsurlarından biri olan kuvvetler ayrılığı ilkesinin de bireysel özgürlükleri kolektif saldırılara karşı koruyan bir kalkan görevi gördüğünü belirtir, “çünkü özgürlüğün kullanılması iktidarın parçalanmasını gerekli kılmaktadır" (Kurt, 2006: 204). Bu durumun temel nedeni de kolektif saldırılara karşı kanun hâkimiyeti korunmak isteniyorsa, yargı bağımsız olmalıdır (Hayek, 2011: 316) tespitine dayanır. Bu bağlamda, iktidarın tek elde toplanıp denetlemeye tabi kılınmadığı totaliter devletlerde hukuk ilkesi egemenliği çiğnenmiş olacağ1 için bireysel özgürlüklerden bahsetmek imkânsızlaşacaktır. Bu gerekçeden dolayı Hayek, liberal toplumsal formasyonlara sahip topluluklarda yaşayan bireyleri özgür bireyler, liberal olmayan toplumlardaki bireyleri ise özgür olmayan bireyler ya da köleler olarak değerlendirir. ${ }^{4}$

Kanun hâkimiyetinin olduğu toplumlarda bireysel özgürlüğü gerçekleştirmenin koşulu olan 'bir alana veya bir mülke sahip olma' durumu Hayek'in bireysel özgürlüğü tanımlamasında başat rolü oynayan bir diğer faktördür. Bir başka deyişle, özgürlüğün negatif boyutundan hareketle bireysel özgürlüğü “...den özgür kılmak”-(freedom from)- şeklinde formüle eden Hayek'in özgürlük tanımında özel mülkiyet, bireyin çevresinden, toplumdan ve devletten gelecek olan keyfi zorlamaya karşı dışlayıcılık özelliği sağlaması itibariyle hayati önemdedir:

"Korunmuş özel bir alanın kabulü, özgürlük dönemlerinde normal olarak bir mahremiyet ve gizlilik hakkını, "insanın evi onun sarayıdır" ve "hiç kimse ferdin hanesi içindeki fiillerine dair bilgi alma hakkında dahi sahip değildir" şeklindeki anlayışı ihtiva etmiştir” (Hayek, 2011: 225).

\footnotetext{
${ }^{4}$ Bu konuda detaylı bilgi için bkz. Friedrich Von, Hayek (1999). Kölelik Yolu, (Çev.) Turhan Feyzioğlu ve Yıldıray Arsan, Ankara: Liberte Yayınları, ss: 19, 26, 45, 91.
} 
Hayek' in yukarıdaki alıntıda yapmış olduğu bu tespit, aynı zamanda bireysel özgürlükleri teminat altına alacak olan hukuk egemenliğindeki yasaların temel görevlerinden birinin de ferdi mülkiyeti korumak olduğu fikrini koşullandırır. Bu doğrultuda, tarihsel mücadeleler sonucunda Batı uygarlığının üzerine inşa edildiği bireysel özgürlüklerin özel mülkiyet ile yekpare bir biçimde ilişkilendirilmesinin Hayek'teki meşru zeminini oluşturan temel unsur, antropolojik çalışmalarla insanın kendisini ancak mülkiyet üzerinden tanımladığında özgürlük idealine yaklaşabileceği ve bireyden türetilen toplum ve devlet formasyonlarının da bu kadim kurum üzerine inşa edildiği varsayımına dayanmaktadır:

“Özel ya da şahsi mülkiyetin (several property) tanınması bu bakımdan zorlanmanın önlenmesi için, yegane değilse bile temel bir koşuldur. Bazı maddi nesnelerin bize mahsus kontrolünden emin olmadıkça, insicamlı bir eylem planı yürütecek bir durumumuz pek olmaz; ve onları kontrol etmediğimiz durumda, diğer insanlarla birlikte faaliyette bulunacak isek zikredilen maddi nesneleri kimin kontrol ettiğini bilmemiz zaruridir. Mülkiyetin tanınması bizi zorlamaya karşı koruyan özel alanın sınırlarının belirlenmesinde pek tabi ilk adımdır; ve öteden beri kabul edilmektedir ki, “özel mülkiyet müessesesinden hazzetmeyen bir halk, özgürlüğün birinci unsurundan mahrumdur” ve "hiç kimse şahsi (several) mülkiyete saldırıp sonra aynı zamanda uygarlığa değer verdiğini söylemede serbest değildir. Bu ikisinin tarihi birbirinden ayrılmaz.” Modern antropoloji, “özel mülkiyetin çok açık bir şekilde ilkel düzeylerde göründüğü” gerçeğini ve "mülkiyetin kaynaklarının-insan ile donun doğal ve yapay çevresel ortamı arasındaki fiziki ilişkileri belirleyen bir legal ilke olarak- kültürel anlamda herhangi bir düzenli eylemin asli ön şartı olduğu gerçeğini teyit etmektedir" (Hayek, 2011: 223).

Ferdiyetçilik ve kolektivizm dikhotomisi üzerinden bireysel özgürlügü negatif boyutta ele alan ve tabiri mümkünse, 'kanun hâkimiyetinde özel mülkiyete dayalı özgürlük’ şeklinde formüle eden Hayek, bireysel özgürlüklerin yaşanacağı mecrayı oluşturacak olan en ideal toplumsal formasyonun da piyasa ekonomisine dayanan bir sosyal düzen olduğunu belirtir. Bir başka ifade ile Hayek'e göre, gerçek özgürlük ve eşitlik ancak özgür bir toplumda yaşanabilir ki, bu bağlamda, özgür toplum: "bireysel özgürlüğün korunduğu, kanun hâkimiyetinin gerçekleştirildiği ve kanun hâkimiyeti ile bağdaşır bir ekonomik siyasal sistemin yani piyasa ekonomisi ve liberal sosyal düzenin bulunduğu toplumdur" (Yayla, 2000: 55). Piyasa ekonomisi sadece bireysel özgürlüğü ve iktisadi etkinliği garanti altına almayacağı aynı zamanda eşitliği de maddi eşitliğin yol açtığı eşitsizliklerden arındırıp gerçek eşitlik olan hukuk önünde eşitlik ve firsat eşitliğine dönüştüreceği için (Hayek, 1999: 52) gerçek özgürlük ve eşitlik nosyonları ancak piyasa ekonomisi üzerine temellenen toplumsal formasyonlarda yaşanacaktır. Daha da önemlisi, bu türden bir eşitlik ve özgürlük ilişkisi, ekonomik ve politik özgürlükleri birbirine koşullandıracağı için, Hayek’teki 
gerçek özgürlük idealinin de hayata geçmesini sağlayacaktır (Eren, 1991: 51). Ez cümle; Hayek’e göre piyasa ekonomisine dayanan bir sosyal düzende birbirinin tamamlayıcısı ve koruyucusu durumunda olan özgürlük ve eşitlik nosyonları, bireysel özgürlükten türetilecek olan ekonomik ve siyasi özgürlüklerin de temel belirleyeni olacaktır.

\section{Kölelikten Özgürlüğe Ya da Maddi Eşitlikten Biçimsel Eşitliğe Giden Yolda Piyasa Ekonomisinin Önemi}

Ferdiyetçilik-kollektivizm dikhotomisi üzerinden ele aldığı özgürlük/özgürsüzlük ve eşitlik/eşitsizlik gibi nosyonların sosyal bir düzende nasıl ortaya çıktığını yine kendisine göre bir dikhotomi olan piyasa ekonomisi ve planlı ekonomi olgularından türeten Hayek'in sosyal teorisinde, piyasa ekonomisi üzerine inşa edilen bir sosyal düzen gerçek özgürlüklerin ve eşitliklerin yaşanmasına zemin hazırlarken, 'planlı/merkezi veya sosyalist bir ekonomi' ${ }^{5}$ modeli üzerine inşa edilen bir toplumsal düzen ise; özgürsüzlüğe/köleliğe ve eşitsizliğe zemin hazırlar.

Her şeyden evvel, Hayek açısından 'kendiliğinden doğan düzen' yani serbest piyasa ekonomisi, insan davranışının özgür bir şekilde gerçekleşmesini sağlayan bir içeriğe sahiptir (Klein, 2014: 139). 'Kendiliğinden doğan düzen' insanlara “herhangi birinin üzerinde girişimde bulunmadığı, toplumun kendi dinamikleri içinde geliştiği, insanların kendi doğal görüntülerini sergileyebildiği”" (Çaha, 2001: 53) bir toplumsal formasyon arz ettiği için kendiliğinden doğan düzen aynı zamanda bireyin özgürlük idealini de açığa çıkaracak ve gerçekleştirecek olan bir düzene tekabül eder. Bu bağlamda, Hayek'in sosyal kuramında piyasa ekonomisi "toplumda gerçekleştirilecek ekonomik faaliyetlerin hiçbir baskıya maruz kalmadan bireyler arası ilişkileri” (Çetin aktaran Yiğit, 2014: 15) düzenlemesi hasebiyle bireysel özgürlüğün gerçek anlamda yaşanmasına zemin hazırlayan bir modeldir. Piyasa ekonomisi bu bağlamda, "ferdi kendi kararlarının nihai hâkimi olarak kabul eden ve ferdin hareketlerine imkân nikbetinde kendi şahsi kanatlarının hâkim olması lazım geldiğini sağlayan yani kısaca ferdiyetçiliğin ruhunu” (Hayek, 1999: 83) oluşturan bir toplumsallaşmayı da beraberinde getirir. Dolayısıyla, Hayek'in gerçek bireysel özgürlüğün yaşanma durumu ile piyasa ekonomisini doğrudan ilişkilendirmesindeki en önemli unsur; özgürlüğün birinci şartı olan kanun hâkimiyetinde/hukuk egemenliğinde yaşanan bir

\footnotetext{
${ }^{5}$ Hayek planlı iktisat kavramı yerine çalışmalarının birçok yerinde aynı anlamda kullandığı merkezi ekonomi, planlı ekonomi, sosyalist ekonomi kavramlarını kullanır. Bkz.: Friedrich Von, Hayek (1999). Kölelik Yolu, (Çev.) Turhan Feyzioğlu ve Yıldıray Arsan, Ankara: Liberte Yayınları, ss: 37, 63, 80, 97.
} 
sosyal düzende bireysel davranışların ancak ve ancak serbest bir piyasa düzeninde gerçekleşebileceği savı yer almaktadır. Serbest rekabet rejiminde, bireysel özgürlüklerin bir uzantısı olan rasyonel ihtiyaçlarımızdan kaynaklı "arzularımızı kimse tatmin etmek istemediği takdirde başka birisine müracaat etme imkânımız vardır ki esasında istifade ettiğimiz seçme hürriyeti bu vakıaya dayanır” (a.g.e: 133). Bu minvalde tekrardan Hayek'in icbar, yasa ve özgürlük formülasyonuna döndüğümüzde şunu ifade etmek son derece mümkündür; Hayek'in sosyal teorisinde icbar tekeline sahip ve yasa uygulayıcısı olan devlet, aynı zamanda gerçek özgürlüğün alanı olan serbest piyasada ferdi hürriyetleri garanti altına alacak olan bir göreve de haiz durumdadır. Hayek tarafından devlete yüklenen bu görev, Hayek’teki devlet anlayışının klasik liberal teorisyenlerin iddia ettiği minimal devlet/gece bekçisi devlet veya 'bırakınız yapsınlar bırakınız geçsinlerci- (laissez faire- laissez passer) devlet anlayışlarından farklı bir devlet içeriğine dayandığını gösterir:

"İktisadi faaliyet özgürlüğü, hukuk hâkimiyeti altındaki özgürlüğü ifade etmiştir, her türlü devlet faaliyetinin yokluğunu değil... Yazarların bir ilke meselesi olarak karşı çıktıkları "müdahale" ya da "müdahalede bulunma", bu nedenle genel hukuk kurallarınca korunacağı düşünülen özel alanın ihlali anlamına geliyordu sadece. Bu yazarlar devletin kendini hiçbir zaman herhangi bir iktisadi faaliyetle meşguliyete vermemesi gerektiğini kastetmişlerdi. Kastettikleri şu idi: Bazı devlet düzenlemeleri vardır ki, bunlar ilke olarak sınırlanmalı ve herhangi bir yerindelik mülahazası (mukteza-i hal) zemininde haklılaştırılamamalı (....) Diğer ifadeyle, hükümet faaliyetinin hacminden ziyade karakteridir önemli olan. İşleyen bir Pazar ekonomisi devlet cenahından bazı faaliyetleri icap ettirir" (Hayek, 2011: 334- 335)

Piyasa ekonomisini devlete önceleyen Hayek'in, geliştirmiş olduğu sosyal teoride kanun hâkimiyetini sağlayacak olan devlete yüklediği görevlerin başında; piyasanın kendiliğinden işlemesini sağlayacak olan adil oyun kurallarını düzenlemek gelmektedir. Piyasa ekonomisinde değişim ve rekabet esas olduğu için bu sistemde herkes kendi amacına sahip olmakla beraber özgür bir şekilde davranabilmektedir (Butter, 2001: 64). Bu oyun her oyundaki gibi sonuç, beceri ve şans faktörlerine dayanır (Yiğit, 2014: 15). Dolayısıyla, kanun hâkimiyeti altında devletin ekonomiye müdahale edeceği ilk unsur rekabet kurallarının piyasada işlerliliğini sağlamaktır: "Rekabetin muhafazası geniş bir “içtimai hizmetler” sistemli ile de pekâlâ bağdaşabilir- yeter ki bu hizmetler rekabeti işlemez bir hale getirecek şekilde teşkilatlandırılmış olmasın” (Hayek, 1999: 51). Demek ki, bireysel özgürlüğün güvence altına alınacağı piyasa düzeninde devletin büyük ve münakaşa götürmez bir faaliyet sahası vardır ki Hayek bu faaliyetleri aşağıdaki şekilde açıklar: 
“Rekabeti mümkün olduğu kadar tesirli kılacak şartları yaratmak, rekabetin tesirli olamayacağı yerlerde onun yerine başka şey ikame etmek. Rekabet sisteminin iyi bir şekilde işlemesi için önceden gerçekleşmesi lüzumlu şartların en esaslısı olan hile ve dolandırıcılığın (cehaletin istismarı da dâhil olmak üzere) önlenmek. Şahsi mülkiyeti korumak.Önemi hiç de az olmayan diğerleri de, ağırlık ve ölçüm standartları koyma; temin edilen kadastral bilgilerin sunulması, arazi tescili, istatistikler vb.; keza bazı eğitim faaliyetlerinin-tanzimi değilse bile- desteklenmesidir” (Hayek, 1999: 53).

Hayek'in sosyal teorisinde devletin yukarıda adı geçen ve bir anlamda da devletin asli görevleri arasında yer alan unsurlar dışında devletin piyasaya müdahalede bulunması doğrudan şahsi hürriyetlerin ilgası anlamına gelecektir. Devletin bu bağlamda, vergilerden elde edilecek olan gelirleri-ister müterakkili (artan oranlı) vergiler aracılığıyla elde edilen gelirler olsun isterse de eşit oranlı vergilerden elde edilen gelirler olsun- yeniden dağıtımı sağlamak yolunda bir araç olarak kullanması ve daha da önemlisi fırsat eşitliğine aykırı olacak davranışlarda bulunması kabul edilemez bir durumdur (Hayek, 2011: 449) Özgür bir toplumda bireysel özgürlüklerin ancak piyasa ekonomisinde ve devlet başta olmak üzere her türlü kollektivitenin kanun hakimiyeti dişına çıkmaması koşuluyla yaşanabileceğini iddia eden Hayek’te bu durumun aksi yaşandığında yani planlı bir iktisat üzerine inşa edilen her türlü sosyal düzende ise özgürsüzlük veya kölelik durumu yaşanacaktır. Çünkü kollektivizmin ferdiyetçiliğe galebe çaldığı toplumsal düzenlerde kurucu özne rolünde olan planlı ekonomi modelleri-başta da sosyalist piyasa ekonomisi olmak üzere- Hayek'in nazarında bireysel özgürlüklere karşı en büyük tehlikeyi oluşturmaktadır:

"Bütün kolektivizm şekillerinin, liberalizm ile ferdiyetçilikten ayrıldıkları nokta şudur: Bunların hepsi cemiyeti topyekün ve bütün kaynaklarıyla tek bir gaye uğrunda teşkilatlandırmak isterler ve ferdi gayelerinin tamamıyla hükümran olduğu serbest sahaların mevcudiyetini kabul etmezler. Kısaca, nazariyat sahasında kolektivizm denilen şeyin beklenmedik, fakat tabii ve zaruri tezahürlerini ifade etmek üzere kullandığımız şu yeni kelimenin hakiki manasıyla, bütün kolektivist sistemler “totaliter"dir" (Hayek, 1999: 79- 80).

Kollektivist ekonomi modellerinin başında gelen sosyalist düzende "hususi teşebbüsün, istihsal vasıtaları üzerindeki hususi mülkiyetin ilgası ve kar temini için çalışan müteşebbisin yerine planlayıcı bir merkezi organizmanın kaim olacağı bir "planlı iktisat” sistemi” (Hayek, 1999: 46) hâkimdir. Bunun bireysel özgürlükleri ortadan kaldırmasının iki temel nedeni vardır. Bunlardan birincisi, tikelin bütüne veya bireyin totaliteye feda edilmesidir. Planlı bir iktisadi düzende "uğrunda bütün cemiyetin teşkilatlandırılıp, seferber edileceği "içtimai gaye” veya "müşterek gaye”, ekseriya "müşterek menfaat”, "umumi refah" yahut "umumi menfaat” gibi müphem tabirlerle piyasaya müdahale gerçekleşmekte ve bireysel özgürlükler sözüm ona toplum adına 
çiğnenmektedir” (a.g.e: 80). Bu bağlamda, kollektivite uğruna icra edildiği iddia edilen iktisadi plancılıkta, iktisadi meselenin, fert yerine camia tarafından halledilmesi durumu vardır ki böyle bir durum, tabiatıyla muhtelif ihtiyaçların nispi ehemmiyetlerini tayin etmek işinin de camiayadaha doğrusu temsilcilerine- bırakılmasını icap ettirecektir (a.g.e.: 128). İkincisi ise; planlı iktisat modellerinin, rasyonel ahlaki olma özelliklerine sahip olan bireyin özgürlüğüne içkin olan 'tercihte bulunma özgürlüğünü’ ferdin elinden almasıdır. Böyle bir düzende bireylerin yerine iktisadi planın idarecisi karar vereceği için "iktisadi plancılık yalnız "kenar ihtiyaç”larımızı, yani en az ehemmiyet verdiğimiz ihtiyaçları, ("münhasıran iktisadi” oldukları için istihfaf edilen ihtiyaçları) müteessir etmekle kalmayıp aynı zamanda hangi ihtiyaçlarımızın ehemmiyetsiz, hangilerinin ehemmiyetli olduğuna bile bizzat devlet verecektir” (Hayek, 1999: 127). Dolayısıyla, planlı iktisadi bir düzende hemen hemen bütün hayatımızın kontrol ve idare altına alınma neticesi açığa çıkmaktadır ki bu durum bireysel kölelikten başka bir şey değildir:

“İptidai ihtiyaçlarımıza veya aile ve dostlarımızla olan münasebetlerimize, yapacağımız işin mahiyetine, boş vakitlerimizi nasıl geçireceğimize varıncaya kadar, iktisadi hayatımızın hemen hemen hiçbir cephesi, nizamı idare edenlerin “şuuri murakabesi”nden kurtulamayacaktır" (Hayek, 1999: 128).

Planlı iktisat modelinin ferdi özgürlüklere tehlike oluşturduğunu biraz da karikatürize ederek açıklayan Hayek'in piyasa ekonomisi ile planlı ekonomi arasında konumlandırdığg özgürlüğün eşitlikle olan ilişkisini analiz edebilmek için eşitliğin Hayek'in nazarında ne anlama geldiğine bakmak gerekir. Her şeyden evvel, Hayek için eşitlik liberal teorinin savunduğu biçimsel hukuk önünde eşitlik anlamına gelmektedir. Hayek tarihsel olarak özgürlük idealinin gerçekleşebilmesindeki “yegâne amacın yasa önünde eşitlik olduğunu” Hayek, 2011: 143) iddia eder. Biçimsel eşitlik gerçek manada yaşanacak olan bireysel özgürlüklerin yol açacağ eşitsizlikleri meşrulaştırma adına hakkaniyetli bir eşitlik anlayışıdır:

"Mamafih genel hukuk ve davranış kuralları bağlamındaki eşitlik, özgürlüğe götüren yegane eşitlik türü olup, keza özgürlüğü tahrip etmeksizin temin edebileceğimiz yegane eşitliktir. Özgürlüğün başka bir eşitlik türü ile hiçbir alakası yoktur. Hatta birçok bakımdan özgürlüğün eşitsizlik doğurması muhakkaktır. Bu, bireysel özgürlüğün zorunlu bir neticesi ve haklı temelde müdafaasının bir cihetidir: Bireysel özgürlüğün neticesi bazı hayat tarzlarının diğerlerinden daha fazla başarıya nail olduğunu ortaya koymamış olsaydı, özgürlükten yana gerekçelerin çoğu ortadan kalkardı" (Hayek, 2011: 143-144).

Kanun hâkimiyetinin hali hazırda uygulamada olan piyasa ekonomisi üzerine inşa edilmiş toplumsal düzenlerde biçimsel eşitliklerin dışına çıkıldığında gerçek manada eşitsizliklerin ve 
gayri adil bir sosyal düzenin ortaya çıkacağı Hayekçi postula, Hayek'in maddi eşitlik söylemleri üzerinden savunulan adalet anlayışlarına bakış açısını da belirler. Bu bağlamda Hayek, tüm insanların fiili eşitliğine dair olgusal bir eşitlik anlayışı üzerinde temellendirilen maddi eşitlik argümanının gerçek eşitlik olamayacağını iddia eder. Çünkü herkesin doğuştan eşitler olarak değerlendirilmesi gerekir şeklinde açığa çığan "maddi eşitlik olgusu, kollektivitenin arzuladığı toplumsal eşitlik kılıfı altında bireysel farklılıkların önüne set çekeceği için bizzat kendisi eşitsizlik durumuna yol açmaktadır" (a.g.e: 24-25) şeklinde değerlendirilir. Oysa Hayek'in nazarında maddi eşitlik argümanlarının merkezinde, Williams'ın da belirttiği üzere, "farklılıklar eğer çok önemli değilse, o zaman özgürlük ve bireysel değer fikri de çok önemli değildir” (Williams, 1953: 23) görüşü yer almaktadır. Dolayısıyla hukuk önünde eşitlik ilkesi, Hayek'in eşitlik formülasyonunda olgusal eşitlikten daha hakkaniyetli olduğu için gerçek özgürlüğün yaşanmasına da zemin hazırlayan yegâne eşitlik anlayışıdır:

“Hakikatin bir ifadesi olarak, "tüm insanların eşit doğduğu” öyle doğru değildir. Bu kutsallaştırılmış ibareyi, tüm insanların hukuki ve ahlaki bakımdan benzer muameleye tabi olmaları lazım geldiğini ifade için kullanmaya devam edebiliriz. Ama bu eşitlik idealinin ne anlama gelebileceğini ve gelmesi gerektiğini anlamak istiyorsak, evvelemirde icap eden, olgusal eşitlik inancından kendimizi kurtarmamızdır (...) argüman bu bireysel farklılıkların, yönetimin o bireylere farklı muamelede bulunması için haklı bir gerekçe arz etmediğini vurgular. Binaenaleyh bu argüman, devletçe gösterilen-eğer fiilen çok farklı olan insanlara hayatta eşit pozisyonlar sağlanacak olsaydı zaruri olacak olan-muameledeki farklılıklara karşı çıkar” (Hayek, 2011: 145-146).

Yukarıda temel hatları çizilen Hayekçi özgürlük, eşitlik ve piyasa ekonomisi ilişkisinde açığa çıkan sosyal ilişkiler yumağının hakkaniyetli bir düzene yol açtığı veya açacağı savının temelinde Hayek' in adalet anlayışı yatmaktadır. Bu bağlamda, Hayek' in adalet anlayışı, "hukuksal ilişkilerde kişilerin bireysel ve subjektif durumlarını dikkate almadan herkesi eşit kabul eden" (Kurt, 2006: 206) adalet türü olan Düzeltici Adalet anlayışına tekabül etmektedir. Yasa önünde eşitlik ilkesiyle doğrudan ilişkili olan bu adalet türü, Aktaş'ın da belirttiği üzere, "Dağıtıcı Adalet anlayışının karşısında" (Aktaş, 2001: 187) yer alır. Hayek'in özgürlüklerin yaşanmasında maddi eşitliklerin gerekliliğini dile getiren Sosyal Adalet veya Dağıtıcı Adalet argümanlarına karşı çıkmasındaki en önemli neden işte tam da bu noktada açığa çıkmaktadır: Dağıtıcı Adalet ve benzeri türden kolektivist adalet anlayışlarında bireysel özgürlükler kollektivite adına feda edilir. $\mathrm{Bu}$ duruma yol açan temel unsurlardan biri de, Dağıtıcı Adalet Anlayışı'nın esasında ekonomik bir açılımın ifadesi olması ve piyasa ekonomisinden kaynaklı gelirlerin yeniden dağıtımını 
meşrulaştırmasıdır (Kurt, 2006: 206). Oysa Düzeltici Adalet anlayışında, ahlaki kuralların belirlenmesinde ve uygulanmasında birey ontolojik bir kategori olarak ele alınmaktadır. Dolayısıyla, Hayek'in Düzeltici Adalet içerisinde yer alan adalet anlayışında bir davranışın adil veya gayri adil bir yargılamaya maruz kalabilmesinin koşulları bireysel eylemler üzerinden tasnif edilir. Bireyin ontolojik bir kategori olarak değerlendirildiği adalet anlayışlarında olduğu gibi Hayekçi adalet anlayışının temelinde Barry’nin de belirttiği üzere, “bireysel eylemler mülkiyet haklarını koruyan ve sözleşmelerin yapılmasında sahtekârlık ve güç kullanmayı yasaklayan genel kurallarla uyumlu iseler adildirler” (Barrry, 2004: 163) görüşü yer almaktadır:

"Maddi eşitliğin karşısında konumlandırılan ideal yasa önünde eşitlik ilkesi aynı zamanda piyasa ekonomisi üzerine inşa edilmiş toplumsal düzenin kurucu özneleri olan bireysel davranışların sonuçlarına uygulanan bir değer ve ahlak ölçütü olduğu için gerçek adalettir” (Hayek, 1994: 85).

\section{Biçimselliğe Saplanmış Bir Özgürlük Masalı mı?: Hayek Üzerine Eleştirel Bir Değerlendirme}

Hayek'in ekonomik indirgemeci bir perspektiften yola çıkarak geliştirmiş olduğu özgürlük teorisinde birey-toplum-devlet formasyonun ontolojik bir kategori olarak bireye içkin k1lınması, beraberinde bazı açmazları da getirmiştir. Bu açmazların temelinde Piyasa Ekonomisi'nin velinimetlerini saymakla bitiremeyen Hayek'in başta planlı iktisadi modeller olmak üzere her türden kolektivizmin, ferdiyetçiliği mahkûm ederek köleliğe ve eşitsizliklere yol açtığı iddiası yer almaktadır. Şüphesiz, Hayek'in birey anlayışı soyut tasarımlar sonucunda yaratılmış atomistik bireyden farklı bir içeriğe sahip olması itibariyle önemlidir. Yine, özgürlük idealinin tarihsel bir momentte açığa çıkmış olduğunu iddia etmesi ve insanın yegâne amacının bu özgürlüğü icra etme veya o yolda mücadele etme olması da takdire şayan bir analizdir. Fakat Hayekçi somut bireye endekslenen özgürlük, eşitlik ve adalet anlayışlarının sosyal düzlemde gerçekleşmesinin önündeki en büyük engel, bizzat biçimsel eşitlikler ve özgürlükler temelinde işleyen piyasa ekonomisinin yol açtığı özgürsüzlük ve eşitsizlik durumlarıdır.

Her şeyden evvel Hayek, bireyin ancak sahip olduğu bir mülk ile kendisini dışarıdan gelecek her türlü tehlikeye karşı koruyacağını ve bu mülkün aynı zamanda bireye özgürlüğünü icra edebilmesi için bir alan yaratacağını iddia etmektedir. Tarih ve modern antropolojinin özel mülkiyet olgusunun ilkel insanlar da bile var olduğu kanıtladığını iddia eden Hayek'in özel mülkiyeti özgürlüğün olmazsa olmaz şartı olarak koşullandırması ve bu durumu tarihsel ve 
antropolojik bir gerçeklik olarak kodlaması tartışılmaya açık bir durumdur. Pek tabi ki de böyle bir girişim bu çalışmanın amacını aşacağ 1 için Hayek'in teorik öncüllerine zemin oluşturan bu argümanının pek tutarlı olmadığına kısaca değinmek gerekecektir. Modern antropologlar, Hayek'in iddia ettiğinin aksine ilkel insanlarda özel mülkiyet kavramının olmadığını, aksine özel mülkiyet kurumunun tarihsel bir momentte sınıflı toplumların ortaya çıkmasıyla belirdiğini göstermiştir. ${ }^{6}$ Tabi burada bu türden bir eleştirinin amacı, özgürlüğü özel mülkiyete içkin olarak tanımlayan Hayek'in teorisinin altını oymaktan ziyade; mülkiyet kurumunun Hayekçi piyasa ekonomisinde yol açacağı özgürsüzlüklerin ve eşitsizliklerin nedeni olan özel mülkiyet kurumunu sorunsallaştırmaktır. Bu bağlamda Hayek, ‘özgürlük nedir?’ sorusuna cevap vermek için k1lı kırk yararcasına yaptığı haritalandırmayı özel mülkiyet nedir? sorusuna uygulamadığı için kavramsal karışıklıkları ortadan kaldıramadığı gibi özel mülkiyet kavramını da çarpıtarak teorik öncüllerini geliştirmiş̧tir denebilir. Mülkiyetin 'kişisel eşyalar olarak mülkiyet' (Property as personal belonging) ve 'üretim aracı olarak mülk' (Property as mean of production) şeklinde bir ayrıma tabi tutulması kannımca bireysel özgürlüğü özel mülkiyete içkin kılan birçok liberal ve liberteryen teorisyenin mülkiyete dair kavramsal çarpıtmaları engellemek adına önemlidir. (Kanatlı, 2021: 28). Böyle bir tespit, haliyle Hayek için de geçerlidir. Zorunlu temel ihtiyaçlardan kaynaklı diş firçası, tarak, pantolon, araba, ev ve benzeri nesneler 'kişisel eşyalar olarak mülkiyet' kategorisinde değerlendirilirken, fabrika, tarım arazisi ve benzeri üretim araçlarına tekabül eden nesneler ise 'üretim aracı olarak mülkiyet' kategorisinde yer alır (a.g.e). Piyasa ekonomisinin lokomotifi olan üretim araçlarının şahsi mülkiyeti bu bağlamda bireyi dıştan gelecek tehlikeye karşı kalkan görevi görecek olan bir araçtan daha fazlası olmayacak mıdır? Ya da Hayekçi bir bakış açısıyla değerlendirildiğinde, şunu söylemek sizce de pek saçma olmayacak mıdır?: Üretici güçlerin gelişmişlik seviyesine paralel bir şekilde yaratılacak olan bolluğun 'herkesten yeteneğine göre herkese ihtiyacına göre' düsturunu benimsemiş olan sosyalist veya herhangi bir planlı iktisadi model üzerine inşa edilmiş bir toplumsal düzende insanlar kendilerine ait bir diş firçaları ve pantolonları olmadığı için özgür de olamayacaklardır! Burada görülmektedir ki; kişiyi dışsal tehditlerden koruyacak olan kişiye ait ev, araba, diş firçası, oyuncak ve benzeri nesnelerin planlı ekonominin uygulandığı toplumsal formasyonlarda olmayacağını iddia etmek, özel mülkiyet kavramının çarpıtılarak üretim araçlarının da aynı işlevi görmesi gerektiği koşullandırmasına yol

\footnotetext{
${ }^{6}$ Bu konuda daha fazla bilgi için bkz.: Edward, Arber. (1885). The First Three English Books on America, London: Birmingham Press.
} 
açmıştır. Bu şekilde oluşturulan teorik öncüllerin Hayek’te ki meşru zemininin bu çarpıtma üzerinden sağlandığını belirtmek gerekir.

İkinci olarak, Hayek kanun hâkimiyetinin omurgasını oluşturan yasa önünde eşitlik ilkesinin, hem adil hem de gerçek eşitlik olduğunu iddia etmekteydi. Bireysel farklılıkların maddi eşitlikler kılıfı altında ortadan kaldırıldığını, dolayısıyla da gerçek eşitliğin ancak ve ancak piyasa ekonomisinde hukuk önünde eşitlik ilkesi ile sağlanabileceğini iddia eden Hayek, yine kavramsal bir çarpıtma ile eşitsizlikler kategorisini tekdüzeleştirmenin yoluna gitmiştir. Beş parmak bir olmaz misali sosyalist planlamacı bir toplumsal düzeni karikatürize eden Hayek'in, bu bağlamda öne sürdüğü temel düşüncelerden biri de doğal eşitsizliklerin bireysel özgürlüklerin yaşanabilmesinde zenginlik olabileceği tezidir. Pek tabi ki de, Hayek'in bahsettiği anlamda olgusal eşitlik yani herkesin sadece insan olduğu için eşit özneler olarak değerlendirilmesi fikri, eşitsiz ve gayri adil bir duruma yol açacaktır. Bir başka deyişle, doğuştan gelen eşitsizliklerin yol açtığı eşitsizler arasında eşitsizlik, eşitler arasında ise eşitlik ilkesini tersten uygulamak gayri adil bir duruma yol açacaktır. Fakat doğal eşitsizliklerin yanına açılacak olan 'yapay eşitsizlikler' kategorisi, Hayek'in eşitlik ve özgürlük anlayışlarının da yeniden değerlendirilmesini sağlayacaktır. Özgürlüğün icra edildiği alan olan sosyal çevrede üretim ilişkilerinden kaynaklı yani doğal olmayan hatta kelimenin tam anlamıyla yapay olan eşitsizliklerin hukuk önünde eşitlik ilkesi ile gerçek eşitlik kategorisine dâhil edilmesi yani eşitliğin tekdüzeleştirilmesi, sorunun asli kaynağına yol açmaktadır. $\mathrm{Bu}$ kaynağın temelinde ise, devletin bu bağlamda yapay eşitsizlikleri giderme yönünde dağıtımcı adalet prensibi ile hareket edebilmesinin yolunun Hayek tarafından tamamen kapatılmış olması yatmaktadır. Yani, negatif özgürlük anlayışının (freedom from) kendisi için bir anlam ifade etmediğinin farkına varan birey, yapay eştisizliklerden kaynaklı bu özgürsüzlük durumunu gerçek anlamda pozitif özgürlük (freedom to) düzleminde gerçekleştirme yolunda atacağı adımları başkasının vicdanına endekslemek zorunda kalmaktadır. Çünkü Hayek’in özgürlük ve eşitlik teorisinde adil bir toplumsal formasyonda ekonomiden kaynaklı yapay eşitsizlikler bireylerin ahlaki özneler olma durumuna koşullandırılarak vicdani bir meseleye indirgenmektedir. $\mathrm{Bu}$ durumu, piyasa ekonomisinin yol açacağı ihtimallerden biri olarak maddi eşitsizlikten kaynaklı fakirlik olgusunu ele alarak örneklendirelim. Hayek, bir taraftan fakirliğin esasında özgürlüğün negatif boyutuna engel teşkil etmediğini vurgularken diğer taraftan da "paranın insan tarafından icat edilen en mühim "hürriyet vasıtalarından" biri olduğunu ve bugünkü cemiyette, para, fakir bir insana dahi muhtelif imkânlar arasında harikulade bir seçme özgürlüğü sağlar” (Hayek, 1999: 125) 
demektedir. Dolayısıyla, Hayek bir taraftan piyasa ekonomisinin olası handikaplarının meşru olduğunu iddia ederken diğer taraftan da ortaya çıkacak olan fakirlik olgusunun sadece ahlaki sorumluluk alınarak çözülebilecek bir durum olarak görmektedir. Hatırlanacağı üzere bireytoplum-devlet formasyonunun kurucu öznesi olan Hayekçi rasyonel ve vicdanl1/ahlaki birey kavrayışı bu gibi durumlarda piyasa ekonomisinin yol açacağı yapay eşitsizlikleri giderme göreviyle tanımlanmıştı. Bir başka deyişle, doğuştan gelmişçesine son derece doğalmış gibi değerlendirilen ama esasında piyasa ekonomisinin yol açtı̆̆ yapay eşitsizlikler Hayek tarafından devlet müdahalesinden azade bir şekilde sadece vicdanlı insanlar tarafından çözülmesi gereken bir olgu olarak formüle edilmiştir. Oysa bu durum aynı zamanda yapay eşitsizliklerin doğal eşitlikler gibi sunulmasına ve her türden eşitsizliğin 'hukuk önünde eşitlik ilkesi' ile aşılacağı yanılsamasına yol açmaktadır. Dolayısıyla, bireysel özgürlükler ancak yasa önünde eşitlik ilkesi sağlandığında icra edilebilir diyen Hayek'in, eşitsizliği sadece doğal eşitsizlikler kategorisi üzerinden ele almış olması, özgürlükle eşitlik arasında kurmuş olduğu ilişkinin de altını oymaktadır.

Hayek' in piyasa ekonomisine indirgemiş olduğu bireysel özgürlüklerin siyasi özgürlüklere öncelenmesi durumu ya da ekonomik özgürlükler olmadan siyasi özgürlükler yaşanamaz yönündeki tespiti de, eleştirilmesi gereken bir diğer husustur. Hatırlanacağı üzere, Hayek'in nazarında siyasi özgürlük gerçek özgürlük olmayıp, özgürlük yanılsamasına meyilli bir özgürlük anlayışına tekabül etmekteydi. Bu yanılsamanın bir nebze de olsa ortadan kalkabilmesinin temel unsuru ise Hayek'in özgürlük teorisinde piyasa ekonomisi üzerine kurulan bir toplumsal formasyonda icra edilecek olan özgürlüklerin 'yasalarla güvence altına alınmış olma şartı'na bağlanmıştı. Fakat Hayek siyasi özgürlük ile ekonomik alandaki özgürlüğü sadece köle-efendi ve yurttaş-yabancı ayrımları üzerinden temellendirdiği için sivil toplumda meydana gelen ekonomisiyaset birlikteliğini ihmal etmektedir. Bu bağlamda, Hayek genel olarak siyasal özgürlüğe dair iki tespitte bulunduğunu hatırlamak gerekir. Bu tespitler:

i-) siyasal özgürlüğe sahip bir birey kölelikten yana oy verebileceği veya kendini bir köle olarak akitle bağlayabileceği için sonuçta bu tür bir özgürlük bireysel özgürlüğü sönümlendirecek bir özgürlük olacaktır.

ii-) siyasal yönetim sürecinde söz sahibi olan bir halkın özgür olacağının garantisi verilemeyeceği gibi oy verme hakkına sahip olmayan fakat piyasa ekonomisinde yer alan bir mülteci de son derece özgür olabilir. 
$\mathrm{Bu}$ iki tespitin açmazda kaldığı husus, ekonomi alanından kaynaklı toplumsal güç matrikslerinin/ilişkilerinin siyaset üzerinde bulunduğu etkilerin ihmalinden kaynaklanmaktadır. Günümüz neo-liberal toplumlarda hukuk önünde eşitlik ilkesinin siyasal eşitlik veçhesindeki yansıması 'reşit olan her vatandaşa eşit oy hakkının tanınmasıdır'. Düzeltici adalet nosyonundan yola çıkıldığında bireylerin siyasi davranışlarının bu şekilde formüle edilmiş olmasının pek tabii ki de bir açmazı bulunmamaktadır. Fakat buradaki sorun kapitalist piyasa toplumunda emeğinden başka satacağı bir şeyi olmayan bireylerin kanun hâkimiyeti altında faaliyetlerini yürüten ve üretim araçlarının özel mülkiyetini koruyan bir devletin bünyesinde ekonomi ve siyaset alanlarında firsat eşitliği ilkesini somut ilişkiler ağında nasıl kullanabileceğidir. Ekonomik olarak yeteri kadar güç sahibi olmayan bireyin (sermaye sahibi veya emekçi) fırsat eşitliği ilkesince piyasanın diğer aktörleri ile Hayekçi piyasa ekonomisinin alâmetifarikası olan rekabet düzleminde mücadele edemeyeceği/edemediği son derece aşikârdır. Devletin biçimsel eşitliklerin uygulayıcısı olan bir hakem olarak belirdiği Hayekçi bir toplumsal formasyonda ekonomik gücü veya uyguladığı lobi sayesinde siyaseten yönetime etkide bulunacak olan bir aktör ile- ki günümüzde ABD başta olmak üzere piyasa ekonomisinin uygulandığı birçok batılı ülkede yaşanan lobicilik-siyaset ilişkisinde açığa çıkan durum budur- bu araçlardan mahrum olan ama firsat eşitliği ilkesi sayesinde özgür olduğu yanılsamasına kapılan bir aktörün siyasete aynı etkide bulunduğunu söylemek son derece iyimser bir bakış açısı sergilememekte midir? Dolayısıyla, Köle-efendi ve yurttaş-yabancı ayrımı üzerinden yapılan Hayekçi siyasi özgürlük kavramsallaştırmasının Hayekçi gerçek özgürlük ile ilişkilendirilmesinde eksik kalan nokta; ekonomik alanda açığa çıkan toplumsal güç matrikslerinin/ilişkilerinin biçimsel eşitlikler kılıfı altında ihmal edilmesi veya çarpıtılmasıdır. Ki bu durum da bizleri, Hayekçi gerçek özgürlük idealinin bir masaldan ibaret olduğu tezini geliştirmeye götürmektedir.

\section{Sonuç}

Piyasa ekonomisinin savunucularından biri olan Hayek’in piyasa ekonomisi, özgürlük ve eşitlik arasında kurmuş olduğu teorik ilişki, günümüzde klasik liberalizmin revize edilmiş hali olan neo-liberalizmin teorik dayanaklarından birini oluşturur. Bireyi ontolojik bir kategori olarak ele alan Hayek, sosyal teorisinin öncüllerini oluştururken soyut atomistik birey anlayışı yerine çevresiyle var olan somut bireye başvurur. Bu birey aynı zamanda rasyonel ve ahlaki davranabilme potansiyeline haiz olan özne olarak Hayek tarafından formüle edildiği için, özgürlük, eşitlik ve adalet gibi toplumsal alana tekabül eden olgular Hayekçi birey üzerinden temellendirilir. Özgürlük, 
eşitlik ve adalet gibi soyutlama aracılığıyla çarpıtılmaya müsait olan kavramların berraklaştırılması için yoğun çaba sarf eden Hayek ideal özgürlüğü bireysel özgürlük, ideal eşitliği ise hukuk önünde eşitlik olarak kodlar. Hayek için adalet ise, piyasa ekonomisinin uygulamada olduğu bir toplumda eşitlik ve özgürlük değerlerinin yaşanıp yaşanmadığını gösteren bir ölçütten fazlası değildir. $\mathrm{Bu}$ bağlamda, ideal özgürlüğün ancak piyasa ekonomisinin adil işleyişi sayesinde gerçekleşebileceğini iddia eden Hayek'te ideal bir toplumsal formasyon da ancak özel mülkiyet kurumunu güvence altına alan, kanun hakimiyetinin var olduğu düzende ortaya çıkabilir. Ne var ki, Hayek'in geliştirmiş olduğu piyasa ekonomisi, özgürlük ve eşitlik arasındaki ilişkide ortaya çıkacak olan ideal bir toplumsal formasyonun yaratılmasında açmazlar mevcuttur. Özel mülkiyet kavramının çarpıtılarak özgürlüğe içkin kılınması, doğal eşitsizlikler ile yapay eşitsizliklerin biçimsel eşitlik/hukuk önünde eşitlik şeklinde tekdüzeleştirilmesi ve her şeyden önemlisi de piyasa özgürlüğünün siyasal özgürlüğe öncelenmesi Hayekçi özgürlük anlayışının/masalının belli başlı açmazlarını oluşturmaktadır.

\section{Kaynakça}

Aktaş, S. (2001). Hayek'in Hukuk ve Adalet Teorisi. Ankara: Liberte Yayınları.

Barry, N. (2004). Modern Siyaset Teorisi, (Çev) Mustafa Erdoğan \& Yusuf Şahin (İkinci Baskı). Ankara: Liberte Yayınları

Boulding, K. (1981). Evolutionary Economics. California: Sage.

Butter, E. (2001). Hayek, (Çev.) Yusuf Ziya Çelikkaya. Ankara: Liberte Yayınları.

Caldwell, B. J. (1988). Hayek's Transformation. History of Political Economy, 20 (4), 543-541.

Cooper, M. (2011). Complexity Theory After The Financial Crisis: The death of neoliberalizm or the triumph of Hayek?. Journal of Cultural Economy, 4(4), 371-385.

Çaha, Ö. (2001). Dört Akım, Dört Siyaset. İstanbul: Zaman Kitabevi.

Edward, A. (1885). The First Three English Books on America. London: Birmingham Press.

Eren, E. (1991). Piyasa Özgürlük ve Eşitlik-Piyasa Sosyalizmi. Bursa: Ezgi Kitabevi

Gallie, W. B. (1955). Essentially contested concepts. Proceedings of the Aristotelian Society, 56 (2), 167-169.

Hayek, F. V. (1994). Kanun, Yasama Faaliyeti ve Özgürlük (Kurallar ve Düzen), (Çev.) Atilla Yayla. İstanbul: Türkiye İş Bankası Kültür Yayınları.

Hayek, F. V. (1999). Kölelik Yolu, (Çev.) Turhan Feyzioğlu ve Yıldıray Arsan. Ankara: Liberte Yayınları. 
Hayek, F. V. (2011). Özgürlüğün Anayasası, (Çev.) Yusuf Ziya Çelikkaya. Ankara: BigBang Yayınları.

Kanatlı, M. (2020). John Rawls'ın Hakkaniyet Olarak Adalet İlkelerinde Özgürlük ve Eşitlik Sorunu Üzerine. Akademik Incelemeler Dergisi, 15(2), 679-712.

Kanatl1, M. (2021). Private Property, Freedom and Order: Social Contract Theories From Hobbes To Rawls. London: Routledge.

Klein, P. G. (2014). F.A. Hayek: Avusturyan Ekonomist ve Sosyal Teorisyen (Çev.) Ünsal Çetin. Liberal Düşünce, 19 (76), 133-145.

Kurt, S. (2006). Hayek'in Özgürlük ve Adalet Teorisi. ZKÜ Sosyal Bilimler Dergisi, 2 (3), 199213.

Neuhouser, F. (2013). Rousseau's Critique of Economic Inequality, Philosophy and Public Affairs, $41(3), 193-225$.

Okyayuz, M. (1999). Yöntembilimsel Bireycilik ve Marksist Toplum Kuramı: Yetmişli Yıllarda Federal Almanya'da Bir Bireycilik/Toplumculuk Tartışması. Marksizm ve Gelecek, 16(1), 71-89.

Rodrigues, J. (2013). The Political and Moral Economies of Neoliberalism: Mises and Hayek. Cambridge Journal of Economics, 37(5), 1001-1017.

Thomas Kurian. Washington: CQ press, 779-780.

Turner, J. (2011). Individualism. içinde The Encyclopedia of Political Science, (Ed.) George

Williams, R. J. (1953). Free and Unequal: The Biological Basis of Individual Liberty. Austin: University of Texas Press.

Yayla, A. (2000). Özgürlük Yolu: Hayek’in Sosyal Teorisi. Ankara: Liberte Yayınları.

Yiğit, G. (2014). Siyaset Felsefesinde Hak, Adalet ve Özgürlük Üzerine: Locke ve Hayek Örnekleri. (Yayımlanmamış Yüksek Lisans Tezi), Süleyman Demirel Üniversitesi Sosyal Bilimler Enstitüsü, Erişim Tarihi ve 07/10/2021, https://tez.yok.gov.tr/UlusalTezMerkezi/tezDetay.jsp?id=HHIov9o4f7sT3hVbdawtpA\&n $\mathrm{o}=$ eocK $3 \mathrm{v} 9 \mathrm{G} 3 \mathrm{pdt} 2 \mathrm{ZMtCyVCg}$ 